\title{
Effect of Heavy Metal, Chromium on Protein and Amino Acid Contents in Gill, Liver and Kidney of Freshwater Fish, Channa striatus (Bloch)
}

\author{
R. Palaniappan ${ }^{1}$ and M. Muthulingam ${ }^{2} *$ \\ ${ }^{1}$ Manonmaniam Sundaranar University, Abishekapatti, Tirunelveli, 627 012, Tamilnadu, India \\ ${ }^{2}$ Department of Zoology, Faculty of Science, Annamalai University, Annamalainagar 608002 , \\ Tamilnadu, India \\ *Corresponding author
}

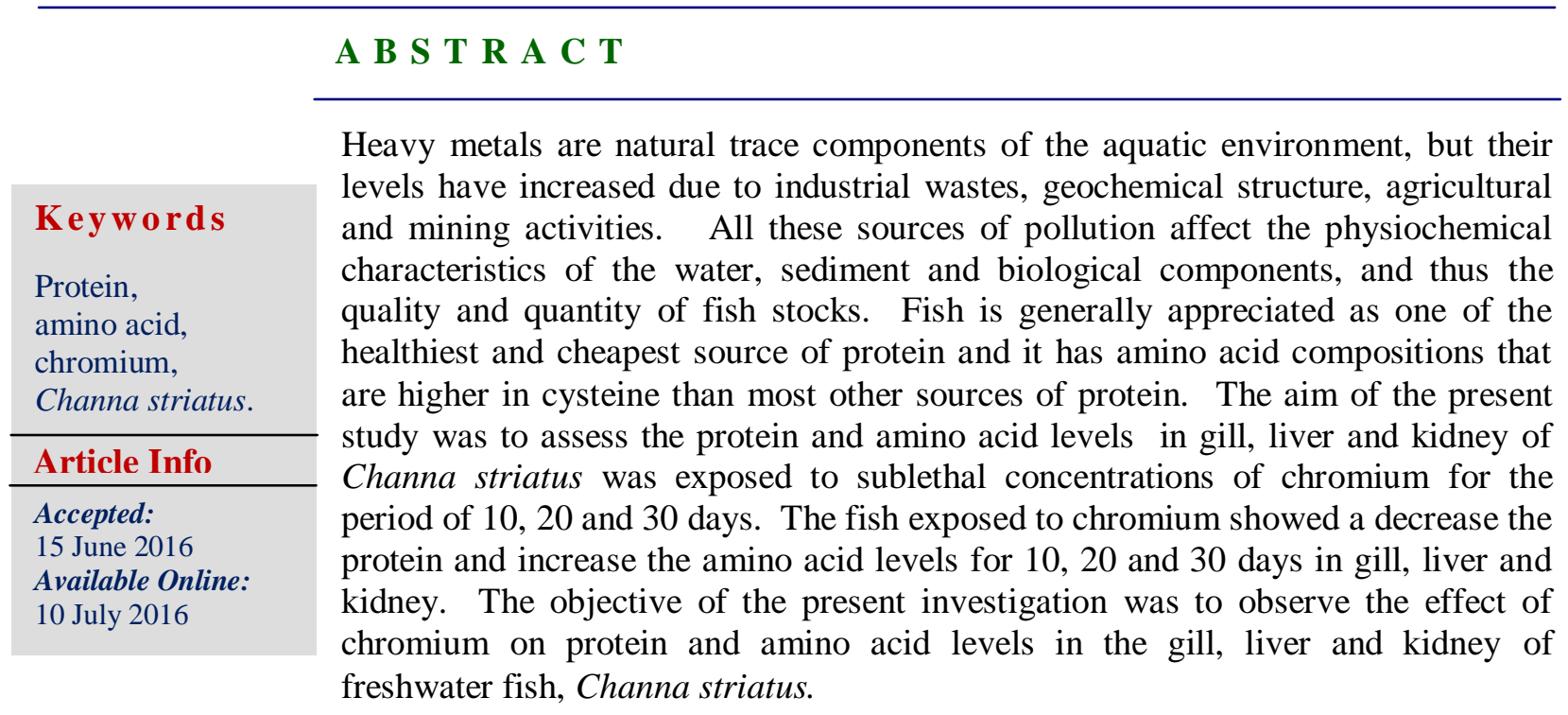

\section{Introduction}

Water contamination caused when an input from human activities cause an increase of a substance in fresh water, sediments and organisms above the natural background level for that area and for those organisms (Clark, 2001). Occurrence of potential toxicants in aquatic ecosystem causes a reduction in the quality of the aquatic environment that results in impaired level of dissolved oxygen (DO), $\mathrm{pH}$, temperature, biological oxygen demand, and chemical oxygen demand (Robert, 2001; Ibrahim et al., 2016).
Increases use of metal based fertilizers in agricultural revolution could result in the continued rises in the concentration of metal pollutants in fresh water due to the water run-off (Adefemi et al., 2008; Prasath and Arivoli, 2008; Ibrahim et al., 2016). The speedy urbanization and industrialization has led to increased disposal of pollutants like heavy metals, radio nuclides, and various types of organic and inorganic substances into the environment. Thus, the industrial wastes are the main source of metal pollution for aquatic organisms. It has 
been cited that the heavy metals constitute the major pollutants in the environment. The heavy metals are important pollutants for fishes, because these are not eliminated from aquatic systems by natural methods, such as organic pollutants, and are enriched in mineral organic substances. The metal contaminants are mixed in the aquatic system through smelting process, effluents, sewage and leaching of garbage which cause severe harm to the aquatic system (Pandey and Madhuri, 2014).

The heavy metals are considered as critical toxic contaminants of aquatic ecosystems, due to their high potential to enter and accumulate in food chain (Olojo et al. 2005). The main sources of heavy metal pollution of the agriculture, industry and metropolitan cities, the bioaccumulation of toxic heavy metals in fish species from different aquatic systems is dependent on their foreign polluted substances. The distribution of heavy metals in water, sediments and fish play a key role in detecting sources of heavy metal pollution in aquatic ecosystem (Forstner and Wittman, 1981). The aquatic systems deposition of contaminants, including heavy metals, can lead to elevated sediment concentrations that cause potential toxicity of the aquatic biota (Yang and Rose, 2003; Heyvart et al., 2000; Maurya and Malik, 2016).

Heavy metals are ubiquitous in the biosphere, where they occur as part of the natural background of chemicals. Anthropogenic activities have also introduced substantial amounts of them into the environment by mobilization from their natural insoluble deposits or environmental sinks (Chiesa et al., 2006). They represent a significant ecological and public health concern due to their toxicity and their ability to accumulate in living organisms. The heavy metals tend to concentrate in the body and cause damage in the kidneys, lungs, brain and nervous system and in the body metabolism (Fergusson, 1990). The $\mathrm{Cr}$ is present in the tannery effluent, and is known to cause various ill effects. Such health hazards are dependent on the oxidation state of $\mathrm{Cr}$. Its hexavalent form is toxic than the trivalent form (Pandey and Madhuri, 2014). The present investigation was to assess the protein and amino acid content in gill, liver and kidney of Channa striatus exposed to sublethal concentrations of chromium.

\section{Materials and Methods}

The fish Channa striatus having mean weight $18-22 \mathrm{~g}$ and length $13-15 \mathrm{~cm}$ were collected from PSP fish farm, at Puthur and acclimatized to laboratory conditions. They were given the treatment of $0.1 \% \mathrm{KMNO} 4$ solution and then kept in plastic pools for acclimatization for a period of two weeks. They were fed twice daily i.e. morning and evening on boiled chicken eggs approximately $4 \%$ of fish body weight divided into two equal meals daily. The chromium was used in this study and stock solutions were prepared. Chromium, LC $_{50}$ was found out for $96 \mathrm{~h}$ (34 ppm) (Sprague, $1971)$ and $1 / 20^{\text {th }}(1.7 \mathrm{ppm}), 1 / 15^{\text {th }}(2.27$ ppm) and $1 / 10^{\text {th }}(3.4 \mathrm{ppm})$ taken as sublethal concentrations for this study. Forty fish were selected and divided into 4 groups of 10 each. The first group was maintained in free from chromium and served as the control. The other 3 groups were exposed to sub lethal concentration of chromium, 10 litre capacity aquaria. The $2^{\text {nd }}, 3^{\text {rd }}$ and $4^{\text {th }}$ groups were exposed to chromium, for 10, 20 and 30 days respectively. At the end of each exposure period, the fish were sacrificed and the required tissues were collected for protein and amino acid estimation. The protein and amino acid content in gill, liver and kidney of Channa striatus were estimated by the method of Lowry et al., 1951 and Moore and Stein (1954) respectively. The data obtained were 
analyzed by applying analysis of variance DMRT one way ANOVA to test the level of significance (Duncan, 1957).

\section{Results and Discussion}

\section{Protein level in gill}

The protein contents were observed in the control gill to be $119.63 \pm 8.74,120.66 \pm$ 8.82 and $122.8 \pm 8.98 \mathrm{mg} \mathrm{g}^{-1}$ wet weight for 10,20 and 30 days respectively. The protein contents were significantly decreased when the fish Channa striatus exposed with low $(102.16 \pm 7.39,96.02 \pm$ 6.95 and $92.53 \pm 6.68)$, medium ( $95.00 \pm$ $6.86,87.33 \pm 6.29$ and $81.92 \pm 5.87)$ and high $(92.11 \pm 6.65,83.19 \pm 5.97$ and 76.71 \pm 5.48 ) sublethal concentrations of heavy metal chromium for 10, 20 and 30 days respectively (Fig 1)..

\section{Protein Level in Liver}

The protein contents were observed in the control liver to be $133.70 \pm 9.82,137.12 \pm$ 10.07 and $142.54 \pm 10.48 \mathrm{mg} \mathrm{g}^{-1}$ wet weight for 10, 20 and 30 days respectively. The protein contents were significantly decreased when the fish Channa striatus exposed with low $(114.52 \pm 8.35,117.88 \pm$ 8.61 and $106.64 \pm 7.75)$, medium (105.44 $\pm 7.66,103.70 \pm 7.53$ and $87.69 \pm 6.31)$ and high $(100.66 \pm 7.30,97.04 \pm 7.02$ and $78.65 \pm 5.62)$ sublethal concentrations of heavy metal chromium for 10, 20 and 30 days respectively. The decrease in the protein content of the liver was more in 30 days of exposed fish compared to 10 and 20 days (Fig 1).

\section{Protein Level in Kidney}

The protein contents were observed in the control kidney to be $89.09 \pm 6.42,89.95 \pm$ 6.48 and $89.33 \pm 6.49 \mathrm{mg} \mathrm{g}^{-1}$ wet weight for 10, 20 and 30 days respectively. The protein contents were significantly decreased when the fish Channa striatus exposed with low $(86.99 \pm 6.26,85.21 \pm$ 6.13 and $80.92 \pm 5.79)$, medium (83.51 \pm $5.99,80.02 \pm 5.73$ and $76.07 \pm 5.43)$ and high $(82.73 \pm 5.93,78.59 \pm 5.62$ and 70.61 \pm 4.51 ) sublethal concentrations of heavy metal chromium for 10,20 and 30 days respectively. The decrease in kidney protein content is more pronounced in high sublethal concentration of heavy metal chromium at 30 days of exposure periods (Fig 1).

\section{Amino Acid Level in Gill}

The amino acid contents were observed in the control gill to be $4.30 \pm 0.33,4.38 \pm$ 0.33 and $4.34 \pm 0.33 \mathrm{mg} \mathrm{g}^{-1}$ wet weight for 10,20 and 30 days respectively. The amino acid contents were significantly increased when the fish Channa striatus exposed with low $(5.46 \pm 0.41,6.26 \pm 0.47$ and $7.57 \pm 0.57)$, medium (5.98 \pm 0.45 , $7.10 \pm 0.54$ and $10.14 \pm 0.77)$ and high $(6.44 \pm 0.49,6.64 \pm 0.65$ and $13.28 \pm 1.01)$ sublethal concentrations of heavy metal chromium for 10,20 and 30 days respectively. In sublethal concentrations of heavy metal chromium exposed fish, Channa striatus the amino acids showed a gradual increase from 10 to 30 days. The maximum increase was noticed in high sublethal concentration of heavy metal chromium at 30 days of exposure periods (Fig 2).

\section{Amino Acid Level in Liver}

The amino acid contents were observed in the control liver to be $6.00 \pm 0.45,6.03 \pm$ 0.45 and $5.98 \pm 0.45 \mathrm{mg} \mathrm{g}^{-1}$ wet weight for 10,20 and 30 days respectively. The amino acid contents were significantly increased when the fish Channa striatus exposed with low $(7.06 \pm 0.54,7.46 \pm 0.56$ 
and $9.67 \pm 0.73)$, medium ( $7.98 \pm 0.61$, $9.77 \pm 0.74$ and $11.56 \pm 0.88)$ and high $(10.14 \pm 0.77,13.58 \pm 1.03$ and $16.30 \pm$ 1.24 ) sublethal concentrations of heavy metal chromium for 10, 20 and 30 days respectively. In sublethal concentrations of heavy metal chromium exposed fish, Channa striatus the amino acids showed a gradual increase from 10 to 30 days. The maximum increase was noticed in high sublethal concentration of heavy metal chromium at 30 days of exposure periods (Fig 2).

\section{Amino Acid Level in Kidney}

The amino acid contents were observed in the control kidney to be $3.76 \pm 0.28,3.82$ \pm 0.29 and $3.80 \pm 0.29 \mathrm{mg} \mathrm{g}^{-1}$ wet weight for 10,20 and 30 days respectively. The amino acid contents were significantly increased when the fish Channa striatus exposed with low $(4.30 \pm 0.33,4.91 \pm 0.37$ and $6.12 \pm 0.46$ ), medium ( $4.94 \pm 0.37$, $5.80 \pm 0.44$ and $6.87 \pm 0.52)$ and high $(5.47 \pm 0.41,7.54 \pm 0.57$ and $9.16 \pm 0.69)$ sublethal concentrations of heavy metal chromium for 10, 20 and 30 days respectively. In sublethal concentrations of heavy metal chromium exposed fish, Channa striatus the amino acids showed a gradual increase from 10 to 30 days. The maximum increase was noticed in high sublethal concentration of heavy metal chromium at 30 days of exposure periods (Fig 2).

Aquatic ecosystems are fragile and at risk primarily because the majority of contaminants derived from urban and industrial sources, abandoned military installations, and agricultural activities are released into rivers (Van der Oost et al., 2003; Pinto et al., 2015; Byrne et al., 2015; Kaur and Dua, 2014). One of the major pollutants is heavy metals, which rapidly accumulate in the body and are slowly metabolized in and excreted from animals. The main source of heavy metal contamination of water is industry which is located nearby water resources. The industrial waste water contain lead $(\mathrm{Pb})$, chromium $(\mathrm{Cr})$, zinc $(\mathrm{Zn})$, and mercury $(\mathrm{Hg})$ are the main polluting heavy metals (Outridge and Noller, 1991; Sabale et al., 2012; Strbac et al., 2015; Silva et al., 2016).

Gills represent a thin and extensive surface in intimate contact with water. They carry out three main functions, gas exchange, ion regulation and excretion of metabolic waste products. Due to the constant contact with the external environment, gills are the first targets of waterborne pollutants (Perry and Laurent, 1993). Gills are the vital organs in fish, which have direct contact with the medium through which pollutants enter into the body (Mount, 1962; Holden, 1972; Edwards, 1973). The liver plays an important role in the synthesis of proteins. The kidney, which is an important organ of excretion and osmoregulation, is indirectly affected by pollutants through blood circulation (Newman and MacLean, 1974). The impact of contaminants on aquatic ecosystem can be assessed by measurement of biochemical parameters in fish that respond specifically to the degree and type of contamination (Petrivalsky et al., 1997). Tissue protein content has been suggested as an indicator of xenobiotic-induced stress in aquatic organisms (Singh and Sharma, 1998). Based on their known toxicological profiles in many animal models, it is certainly plausible that waterborne metals could alter physiological and biochemical parameters in fish (Abedi et al., 2013).

The protein contents were decreased may be due to breakdown of proteins in the fabrication of some amount of energy for organism (Tulasi and Jayantha Rao, 2013). Sathyanarayana (2005) suggested that the 
physiological status of animal is usually indicated by the metabolic status of proteins. Jrueger et al. (1968) reported that the fish can get the energy through the catabolism of proteins. Proteins are mainly involved in the architecture of the cell, which is the chief source of nitrogenous metabolism. Thus, the depletion of protein fraction in liver, brain and kidney tissues may have been due to their degradation and possible utilization for metabolic purposes. Increases in free amino acid levels were the result of breakdown of protein for energy and impaired incorporation of amino acids in protein synthesis (Singh et al., 1996).

Fig.1 Protein levels changes (mg/g) in gill, liver and kidney of Channa striatus exposed to sublethal concentrations of chromium
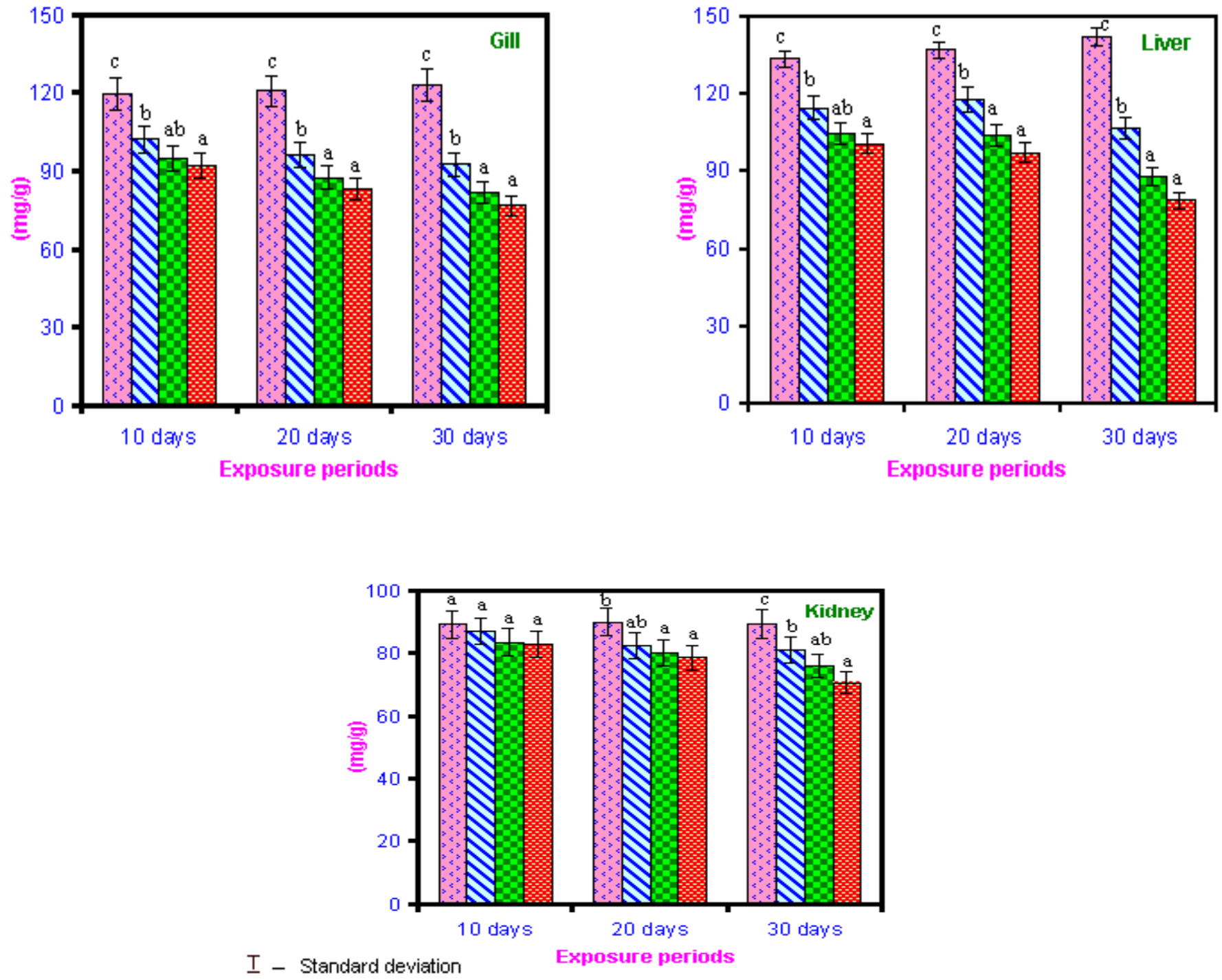

Control $\mathbf{\Delta}$ Low concentration $\mathbf{Q}$ Medium concentration 圈 High concentration 
Fig.2 Amino acid content changes (mg/g) in gill, liver and kidney of Channa striatus exposed to sublethal concentrations of chromium
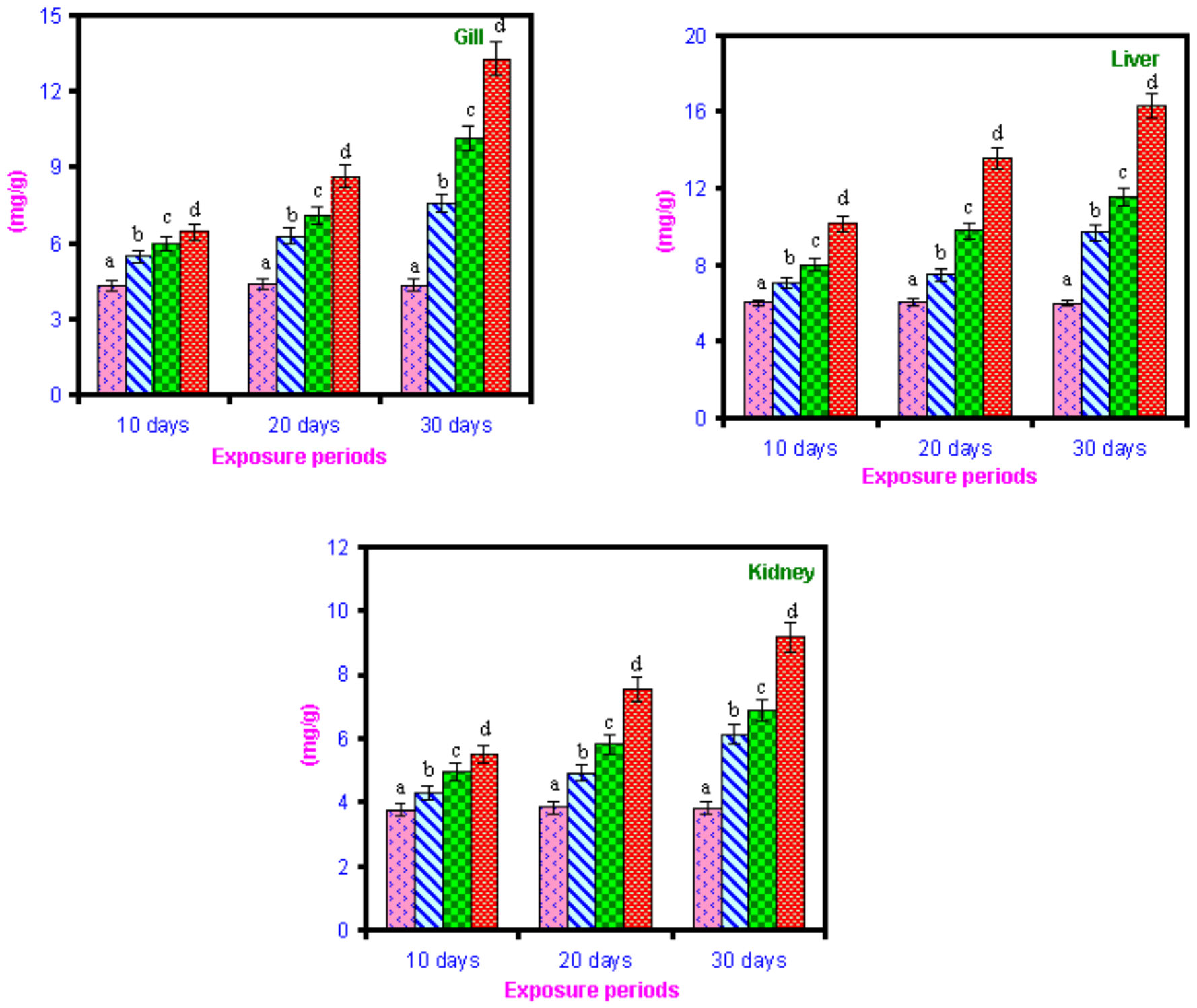

I - Standard deviation

Control $\mathbf{\Delta}$ Low concentration $\mathbf{B}$ Medium concentration 罍 High concentration

The present investigation, in the gill, liver and kidney protein content had decreased whereas amino acids content had increased at all periods of exposure when Channa striatus was exposed with sublethal concentrations of chromium for the periods of 10, 20 and 30 days exposure. The free amino acid (FAA) pool was increased in the 
tissues of the fish during exposure to lihocin (Abdul et al., 2010), while the elevated FAA levels were utilized for energy production by supplying them as keto acids into TCA cycle through aminotransferases to contribute energy needs during toxic stress. Increases in free amino acid levels were the result of breakdown of protein for energy and impaired incorporation of amino acids in protein synthesis (Singh et al., 1996). Simillarly protein levels were decreased and amino acid contents increased significantly in gill, liver and kidney of Cyprinus carpio exposed to sublethal concentration of pharmaceutical effluent (Muthulingam et al., 2011).

The protein content decreased in the liver, brain and kidney tissues of Channa punctatus during lihocin treatment (Abdul et al., 2010). A reduction in the protein content in the kidney could possibly be due to protein breakdown leading to increased amino acid pool of tissue (Radhaiah et al., 1987). Satyaparameshwar et al., (2006) suggested that Lamellidens marginalis exposed to sublethal concentration of chromium showed decrease the protein and RNA where as amino acid level was elevated. The decreased protein level was observed in the kidney tissue of Catla catla at sublethal concentration of chromium (Vincent et al., 1995). Rao et al. (1980) and Devi (1981) have reported that the kidney was the site of degradation and detoxification of toxic substances. The decreased protein level in the kidney tissue at sublethal concentration of lead may be due to the enhanced proteolysis.

Many investigators have also recorded such a reduction in protein content in fishes exposed to different toxicants (Karuppasamy, 1990; Rao, 1989; Vincent et al., 1995; Nisha and Shukla, 1986). A reduction in the protein content in the present investigation in Channa striatus suggests that the tissue protein undergoes proteolysis, which results in an increase in the production of free amino acids. These amino acids are utilized for energy production during stressful situation in the intoxicated fishes. Moorthikumar and Muthulingam (2010) reported that decline in the protein and elevated contents of amino acid in liver, kidney and brain of Labeo rohita under heavy metal, nickel chloride stress. Senthil Elango and Muthulingam (2014) suggested that decreasing patterns of protein and increased levels of amino acid contents in brain and muscle of Oreochromis mossambicus was exposed to sublethal concentrations of chromium. It is evident that proteins are degraded to meet the energy requirements during sublethal concentrations of chromium. The depletion in protein level was due to diversification of energy to meet the impending energy demand when the fish Channa striatus exposed to sublethal concentrations of heavy metal chromium.stress. The reduction in protein content in the present study indicates that the tissue protein undergoes proteolysis resulting in the production of free amino acids leads to disturbances in the physiological activity of the fish Channa striatus.

\section{Acknowledgement}

The authors wish to thank the authorities of Manonmaniam Sundaranar University and Professor and Head, Department of Zoology, Annamalai University for providing the facilities to carry out the research work.

\section{References}

Abedi, Z., Hasantabar, F., Khalesi, M.K and Babaei, S. 2013. Effect of Sublethal Concentrations of Cadmium, Lead and Chromium on Some Enzymatic Activities of Common Carp, Cyprinus carpio. World J. Zool., 
8(1): 98-105.

Abdul, N., C. Janaiah and P. Venkateshwarlu. 2010. The effects of lihocin toxicity on protein metabolism of the fresh water edible fish, Channa punctatus (Bloch). J. Toxicol. Environ. Health Sci., 3(1): 018-023.

Adefemi, S.O., Asaolu, S.S., Olaofe, O., 2008. Determination of Heavy metals in Tilapia mossambicus Fish,Associated water and Sediment fom Ureje Dam in South Western, Nigeria. Res. J. Environ. Sci., 2: 151155.

Ahmed, Th. A Ibrahim, Ekbal, T. Wassif and Mariana S Alfons., 2016. Heavy Metals Assessment in Water, Sediments and Some Organs of Oreochromis niloticus under the Impact of Sewage Water. J. Heavy Metal Toxicity and Dis., 1(1:4) : 1-7.

Byrne, S., Miller, P., Waghiyi, V., Buck, C. L., von Hippel, F. A., and Carpenter, D. O. 2015. Persistent organochlorine pesticide exposure related to a formerly used defense site on St. Lawrence Island, Alaska: Data from sentinel fish and human sera. $J$. Toxicol. Environ. Health A, 78: 976992.

Clark, R.B. 2001. Marine Pollution, Fifth edition, Oxford Univ. Press, pp 237.

Devi, A.P. 1981. Studies on the toxicity of endosulfan to some fresh water fish with special reference to certain physiological changes induced in Channa punctatus (Bloch.). Ph.D. Thesis, Nagarjuna University.

Duncan, B.D. 1957. Multiple range tests for correlated and heteroscedastic means. Biometrics, 13: 359 - 364.

Edwards, C.A. 1973. Environmental pollution by pesticides Pleunum press, London. New York, 1- 3.

Forstner, U., Wittman, G.T.W. 1981. Metal Pollution in the Aquatic Environment,
Springer-Verlag, Berlin, Heidelberg, NY.

Heyvart, A.C., Reuter, J.E., Sloton, D.G. and Goldman, C.R. 2000. Paleolimnological reconstruction of historical atmospheric lead and $\mathrm{Hg}$ deposition at lake Tahoe, California, Nevada" Environ. Sci. Technol., 34: 3588-3597.

Holden, A.V. 1972. The effects of pesticides on life in freshwater. Proc. Soc. Lon. B., 180: 383 - 394 .

Jrueger, H.W., J.B. Saddler, G.A. Chapman, I.J. Tinsely and R.R Lowry., 1968. Bioenergetics, exercise and fatty acids of fish. J. Am. zool., 8: 119.

Karuppasamy, R. 1990. Toxicity impact of sugar mill effluent on freshwater fish Channa punctatus (Bloch.). M.Phil Thesis, Annamalai University.

Kaur, R., Dua, A., 2015. Scales of freshwater fish Labeo rohita as bioindicators of water pollution in Tung Dhab Drain, Amritsar, Punjab, India. J. Toxicol. Environ. Health A, 78: 388-396.

Lowry, O.H., N.J. Rosebrough, A.L. Farr and R.J. Randall, 1951. Protein measurement with the Folin-phenol reagent. J. Biol. Chem., 193: 265-275.

Maurya, P.K and D S. Malik., 2016. Distribution of heavy metals in water, sediments and fish tissue (Heteropneustis fossilis) in Kali River of western U.P. India. Int. J. Fisheries and Aquatic Studies, 4(2): 208-215.

Moore, S. and W.H. Stein. 1954. A modified ninhydrin reagent for the photometric determination of amino acid and related compounds. J. Biol. Chem., 211: 907-913.

Mount, D.I. 1962. Chronic effects of endrin on blunt nose minnows and guppies. U.S. Fish Wild Serv. Res. Rept., 58: 138.

Moorthikumar, K., and Muthulingam, M., 
2010. Shifts in protein metabolism in liver, kidney and brain of Indian major carp, Labeo rohita (Hamilton) under heavy metal, nickel chloride stress. Int. J. Curr. Res., 7: 014-017.

Muthulingam, M., N. Indra., P. Ronald Ross and S. Ravichandran. 2011. Effect of Pharmaceutical effluent on protein and amino acid content changes in freshwater fish Cyprinus carpio L. J. Sci. Trans. Environ. Technov., 4 (3): 127 - 133.

Newman, M.W. and MacLean. 1974. Physiological response of the cunner Tautogoloborous adspersus to cadmium VI: Histopathology No. A Tech. Report, NMFS, SSRF, 681.

Nisha and N.P. Shukla. 1986. Effect of textile liquid effluent on the freshwater fish. Indian J. Environ. Protec., 6(3): 189-192.

Olivares-Rieumont, S., Rosa, D., Lima, L., Graham, D.W., Alessandro, K.D. and Borroto, J. 2005. Assessment of heavy metal levels in Almendares River sediments-Havana City, Cuba. Water Res., 39: 3945-3953.

Outridge, P.M., and Noller, B.N. 1991. Accumulation of toxic trace elements by freshwater vascular plants. Rev. Environ. Contam. Toxicol., 121: 1-63.

Pandey, G and Madhuri, S. 2014. Heavy Metals Causing Toxicity in Animals and Fishes. Res. J. Animal, Veterinary and Fishery Sci., 2(2): 17-23.

Perry, S.F. and P. Lauvent. 1993. Environmental effects on fish gill structure and function. In: Rankin, J.C. and F.B. Jensen (eds.), Fish Ecophysiology, Chapman and Hall, London, pp. 231-264.

Petrivalsky, M., M. Machala, K. Nezveda, V. Piacka, Z. Svobodova and P. Drabek, 1997. Glutathione dependent detoxifying enzymes in rainbow trout liver: search for specific biochemical markers of chemical stress. Environ. Toxicol. Chem., 16: 1417-1421.

Pinto, M. F., Louro, H., Costa, P. M., Caeiro, S., and Silva, M. J., 2015. Exploring the potential interference of estuarine sediment contaminants with the DNA repair capacity of human hepatoma cells. J. Toxicol. Environ. Health A, 78: 559-570.

Prasath, P.M.D., Arivoli, S. 2008. Biochemical study of freshwater fish Catla catla with reference to mercury chloride. Iranian J. Environ. Health Sci. Eng., 3: 109-116.

Roberts, R.J. 2001. Fish Pathology, $3^{\text {rd }}$ Ed. W.B. Saunders, Philadeiphia, Pennsylvania, pp. 472.

Radhaiah, V., M. Girija and K. Jayantha Rao. 1987. Changes in selected biochemical parameters in the kidney and blood of the fish, Tilapia mossambicus (Peters) exposed to heptachlor. Bull. Environ. Contam. Toxicol., 39: 1006-1011.

Rao, D.M., A.P. Devi and A.S. Murthy, 1980. Relative toxicity of endosulfan, its isomers and formulated products to the freshwater fish Labeo rohita. J. Toxicol. Environ. Hlth., 6: 323.

Rao, D.M.R. 1989. Studies on the relative toxicity and metabolism of endosulfan to the Indian major carp Catla catla with special reference to some biochemical changes induced by the pesticides. Pest. Biochem. Physiol., 33: 220-229.

Sabale, S.R., Tamhankar, B.V., and Dongare, M.M. 2012. Extraction, determination and bioremediation of heavy metal ions and pesticide residues from lake water. $J$. Bioremediat. Biodegrad., 3: 1-8.

Sathyanarayana, U. 2005. Biochemistry book and allied (P) Ltd. 8/1 Chintamani Das Lan Kolkata 700009 India, pp. 349. 
Satyaparameshwar, K., Ravinder Reddy, T and Vijaya Kumar, N., 2006. Effect of chromium on protein metabolism of fresh water mussel, Lamellidens marginalis. J. Environ. Biol., 27(2): 401-403.

Senthil Elango, P., Muthulingam, M. 2014. Impact of heavy metal chromium on protein and aminoacid contents in brain and muscle of freshwater fish Oreochromis mossambicus (Peters), Int. J. Curr. Res., 6(01): 4841-4845.

Silva, S.V.S., Diasa, A.H.C., Dutra, E.S., Pavanin, A.L., Morelli, S and Pereirad, B.B., 2016. The impact of water pollution on fish species in southeast region of Goias, Brazil, J. Toxicol. Environ. Heal, Part A, 79 (1): 8-16.

Singh, A., D.K. Singh, T.N. Mishra and R.A. Agarwal., 1996. Molluscicides of plant origin. J. Biological Agric. Hortic., 13: 205-252.

Singh, R.K. and B. Sharma, 1998. Carbofuran induced biochemical change sin Claria batrachus. Pestic. Sci., 53: 285-290.

Sprague, J.B. 1971. Measurement of pollutant toxicity to fish. III sublethal effects and safe concentrations. Water. Res., 5: 245-266.

Strbac, S., Kašanin-Grubin, M., Jovančićević, B., and Simonović, P. 2015. Bioaccumulation of heavy metals and microelements in silver bream (Brama brama L.), northern pike (Esox lucius L.), sterlet (Acipenser ruthenus L.), and common carp (Cyprinus carpio L.) from Tisza River, Serbia. J. Toxicol. Environ. Health A 78: 663-665.

Tulasi, G and Jayantha Rao, K., 2013. Effect of chromium on protein metabolism in different tissues of fish, Cyprinus carpio. Res. J. Pharmaceutical, Biological and Chemical Sci., 4(1): $143-148$.

Van der Oost, R., Beyer, J., Vermeulen, N. P. 2003. Fish bioaccumulation and biomarkers in environmental risk assessment: A review. Environ. Toxicol. Pharmacol., 13: 57-149.

Yang, H., Rose, N.L. 2003. Distribution of $\mathrm{Hg}$ in the lake sediments across the $\mathrm{U}$. K Sci. Total Environ., 304: 391-404.

\section{How to cite this article:}

Palaniappan, R., and Muthulingam, M. 2016. Effect of Heavy Metal, Chromium on Protein and Amino Acid Contents in Gill, Liver and Kidney of Freshwater Fish, Channa striatus (Bloch). Int.J.Curr.Microbiol.App.Sci. 5(7): 372-382. doi: http://dx.doi.org/10.20546/ijcmas.2016.507.040 